\title{
Pemakaian Bahasa Persuasif Media Luar Ruang selama Masa Pandemik Covid- 19 di Dusun Nyangkringan, Kelurahan Bantul, Kecamatan Bantul, DIY
}

\author{
Rudi Ekasiswanto, Ridha Mashudi Wibowo \\ Departemen Bahasa dan Sastra, Prodi Bahasa dan Sastra Indonesia \\ Korespondensi: rudilada13@yahoo.com
}

\begin{abstract}
The use of appropriate language by speakers has been proven to be able to convey messages clearly to the speech partners that they want, and it can even further change the behavior of the speech partners. This can be exemplified by the use of persuasive language in outdoor media. In order to get considerable attention, outdoor media installation is usually installed in a strategic location. The billboards that are installed, for example, are designed to be large and permanently installed within a certain period of time. The information displayed in billboards is arranged with the right diction, special sentence structure, and has a strong persuasive impact supported by an attractive design. Unfortunately, not all community members have the ability to make representative billboards. Community service activities in Nyangkringan village are aimed to develop two abilities, namely the ability to use language effectively and also to design attractive and informative-persuasive billboards. After receiving adequate guidance, the community service activity participants have been able to create billboards that are memorable and informative-persuasive. The installation of billboards at a later stage of the project indicates a significant change in behavior due to increased public awareness of the Covid-19 pandemic. It is hoped that with the abilities that they already have, in the future, the community service participants can make the necessary outdoor media according to their designation.
\end{abstract}

Keywords: persuasive language; outdoor media; behavior change; the Covid-19 pandemic

\begin{abstract}
Abstrak
Pemakaian bahasa penutur secara tepat telah terbukti dapat menyampaikan pesan dengan jelas kepada mitra tutur yang dikehendakinya, bahkan lebih jauh lagi dapat mengubah perilaku mitra tutur. Hal ini dapat dicontohkan dengan pemakaian bahasa persuasif di media luar ruang. Agar dapat memperoleh perhatian yang cukup besar pemasangan media luar ruang biasanya dilakukan di lokasi yang strategis. Baliho yang dipasang, misalnya, didesain berukuran besar dan dipasang secara permanen dalam rentang waktu tertentu. Informasi yang dipajang di dalam baliho disusun dengan diksi yang tepat, struktur kalimat khusus, dan berdampak persuasif yang kuat didukung dengan desain yang menarik. Sayangnya, tidak semua anggota masyarakat memiliki kemampuan membuat baliho yang representatif. Aktivitas pengabdian kepada masyarakat di Dusun Nyangkringan kali ini ditujukan untuk mengembangkan dua kemampuan, yakni kemampuan menggunakan bahasa secara efektif dan mendesain baliho yang menarik dan informatif-persuasif. Setelah mendapat bimbingan yang memadai, peserta kegiatan pengabdian dapat mewujudkan baliho yang mengesankan dan informatif-persuasif. Pemasangan baliho pada tahap selanjutnya mengindikasikan perubahan perilaku yang signifikan atas meningkatnya kesadaran masyarakat terhadap pandemi Covid-19. Diharapkan dengan
\end{abstract}


kemampuan yang telah dimiliki pada masa depan, para peserta pengabdian dapat membuat media luar ruang yang diperlukan sesuai dengan peruntukannya.

Kata kunci: bahasa persuasif; media luar ruang; perubahan perilaku; pandemi Covid-19

\section{Pendahuluan}

Media luar ruang merupakan sarana penyampai informasi kepada khalayak ramai yang letaknya di ruang terbuka atau ruang publik, seperti di pinggiran jalan, di tengah pusat keramaian, atau di tempat lain yang mudah terlihat oleh banyak orang. Letaknya yang strategis menjadikan media luar ruang sebagai fokus perhatian masyarakat dalam memperoleh informasi yang ada di sekitar mereka. Berkaitan dengan hal ini, pada masa pandemi covid-19 ini, penggunaan bahasa harus diperhatikan pada setiap penulisan media luar ruang. Oleh karena itu, bahasa yang digunakan harus tepat, eksplisit, dan benar. Bahasa yang tepat, jelas, dan benar hendaknya mengikuti kaidah bahasa Indonesia. Bagian yang perlu diperhatikan dalam pemakaian bahasa Indonesia luar ruang ini adalah penggunaan ejaan, pemilihan kata (diksi), dan struktur kalimat. Sering kali media luar ruang menggunakan bahasa yang tidak mengikuti kaidah bahasa yang berlaku. Penggunaan bahasa asing dan bahasa daerah pada media luar ruang yang tidak pada tempatnya juga memberi pengaruh terhadap penggunaan bahasa Indonesia. Selain itu, aspek fisik media luar ruang juga perlu diperhatikan. Fisik dalam hal ini terdiri atas lokasi, ukuran, sifat, dan dampak pemasangan media luar ruang tersebut. Sebagian besar, media luar ruang berada pada lokasi yang strategis, berukuran besar, bersifat permanen, dan memiliki dampak terhadap bahasa masyarakat secara masif (Nurkumala et al., 2017:1). Jadi, jika bahasa yang digunakan pada penulisan media luar ruang yang berada pada lokasi yang strategis, berukuran besar, dan permanen itu belum tepat, hal tersebut dapat memengaruhi penggunaan bahasa bagi pembaca sehari-hari.

Bahasa persuasif media luar ruang pada masa pandemi Covid-19 dipilih sebagai tema pengabdian kepada masyarakat di Dusun Nyangkringan, Bantul, Bantul DIY dengan beberapa alasan. Pertama, media luar ruang merupakan sumber informasi yang menarik untuk dibaca oleh masyarakat. Kedua, media luar ruang relatif berbentuk besar dan mencolok sehingga mudah dilihat oleh masyarakat. Ketiga, media luar ruang memiliki jangka waktu pemasangan yang relatif lama. Keempat, diperlukan kemampuan dan keterampilan yang mencukupi untuk dapat membuat media luar ruang yang dapat menjangkau seluruh lapisan masyarakat sehingga mampu memengaruhi bahasa dan setidaknya perilaku masyarakat setempat secara masif ( $c f$. Hasanudin, 2017; Nurkumala, 2017).

\section{Pedekatan Pelaksanaan Program}

Aktivitas pengabdian kepada masyarakat ini bertujuan agar, pertama, warga masyarakat dapat mengembangkan kemampuan dan keterampilan, khususnya pengurus kampung Nyangkringan, Takmir Masjid An-Nur, pemuda-pemudi Karang Taruna Ganyang, dan kelompok ronda untuk dapat memakai bahasa Indonesia secara baik dan benar sesuai peruntukannya, khususnya pemakaian bahasa Indonesia secara persuasif dalam media 
luar ruang seperti banner, spanduk, edaran, dan billboard. ${ }^{1}$

Kedua, warga masyarakat mampu mendesain media luar ruang secara efektif sehingga informasinya dapat diterima masyarakat luas secara presisi dan berkualitas. Sudah menjadi pemahaman awam bahwa pada awal masa pandemi ini banyak jalan kampung ditutup dengan spanduk bertopik isolasi mandiri (lockdown). Dari sejumlah pengamatan sementara atas 100 spanduk yang dipasang di banyak mulut gang dapat disimpulkan bahwa pemakaian bahasa, khususnya ejaan, pemilihan kata (diksi), dan struktur kalimat, dalam spanduk-spanduk itu dapat dikelompokkan menjadi beberapa jenis, yaitu jenis pemakaian kalimat suruh/imperatif (42\%), kalimat informatif (38\%), kalimat persuasif/bujukan (14\%), dan kalimat yang mengandung kekerasan verbal (6\%) (Wibowo, 2020:3). Dengan melihat persentase itu dapat dipahami bahwa pemakaian kalimat imperatif lebih dominan daripada yang lain. Hal ini dapat dipahami karena Covid-19 adalah pandemi yang harus segera ditangani sehingga kalimat suruh yang di dalamnya terkandung petunjuk/pedoman untuk menghindari wabah itu sangat diperlukan untuk menggugah kesadaran masyarakat atas kesehatan bersama. Hasil pengamatan ini cukup membuktikan bahwa penggunaan media luar ruang yang besar dan mencolok punya kontribusi terhadap perilaku pembacanya.

Dusun Nyangkringan adalah salah satu dusun di antara 12 dusun di dalam Kelurahan Bantul ${ }^{2}$. Dusun Nyangkringan ditetapkan sebagai sasaran aktivitas pengabdian karena profesi masyarakatnya yang sangat beragam dan letaknya di area yang strategis di pusat kota. Masyarakatnya dinamis dan dominan berprofesi sebagai pedagang dan usaha kecil rumahan. Pada masa pandemik Covid-19, banyak media luar ruang tentunya yang dibuat untuk mencegah penularan virus Covid-19 sesuai dengan protokol kesehatan karena tidak dapat dihindari arus masuk dan keluar pembeli serta distributor ke wilayah ini. Mengingat arus masuk dan keluar yang tinggi, diperlukan keterampilan untuk menggunakan bahasa secara santun, informatif, dan persuasif agar komunikasi antarwarga tetap terjalin dengan baik, di samping terus memberi pengarahan agar kesadaran kesehatan mereka terjaga. Pengurus kampung, takmir masjid, kelompok ronda, dan pemuda-pemudi melalui Karang Taruna Ganyang didorong untuk dapat memberi teladan agar dapat menciptakan suasana yang kondusif melalui penyampaian informasi yang benar dengan menggunakan bahasa dalam media luar ruang yang efektif, mengena, dan tidak multitafsir. Mengikuti pandangan Nugroho (2010:7) untuk dapat membuat media luar ruang yang tepat sama seperti berlangsungnya proses komunikasi periklanan yang di dalamnya diperlukan lima syarat, yakni orang yang tepat, tempat yang tepat, waktu yang tepat, pesan yang tepat, dan sarana yang tepat. Berkaitan dengan kebutuhan bahasa persuasi dan media luar ruang dirasakan perlu untuk memberi edukasi, peringatan dini, informasi yang kontinu dan masif guna pencegahan wabah Covid-19, dan mengajarkan kesadaran hidup sehat secara pribadi dan sosial.

Aktivitas pengabdian kepada masyarakat ini dilakukan dengan memberi pelatihan secara daring dan konsultasi bahasa secara persuasif untuk media luar ruang sepanjang masa pandemi Covid-19 kepada pengurus kampung Nyangkringan, takmir masjid An-

1 https://mediamove.id/jenis-jenis-media-luar-ruangan-yang-paling-poluler/; https:// solusiprinting.com/ ber-bagai-kelebihan-dan-kekurangan-media-luar-ruang/

2 https://kusnantokarasan.com/2015/11/01/nama-nama-dusun-desa-dan-kecamatan-sekabupaten-bantul/ 
Nur, kelompok ronda, dan pemuda-pemudi Karang Taruna Ganyang. Kegiatan yang dilakukan difokuskan untuk dapat menghasilkan dua hal, yakni kemampuan keras dan kemampuan lunak. Memiliki kemampuan keras berarti warga masyarakat mampu membuat media luar ruang secara efektif, berkualitas, dan tepat sasaran, sementara memiliki kemampuan lunak dimaksudkan agar warga masyarakat berangsur-angsur mempunyai pemahaman dan keterampilan dalam membuat desain media luar ruang yang benar secara bahasa, ekspresif, santun, dan persuasif. Pelatihan disajikan melalui handout, penugasan, dan sumbang saran kontributif atas perkembangan kemampuan penulisan media luar ruang yang dilakukan para pengurus kampung takmir masjid An-Nur, kelompok ronda, dan pemuda-pemudi Karang Taruna Ganyang. Diharapkan dengan pelatihan itu, kemampuan mereka dalam menggunakan bahasa dapat dikembangkan. Selain itu, dapat dilihat pula perkembangan keterampilan mereka dari media luar ruang yang dihasilkan dari waktu ke waktu. Pada bagian akhir pelatihan dievaluasi kesalahan umum (general mistakes) dan contoh-contoh terbaik (best practice) agar mereka memiliki pemahaman yang kuat terkait dengan bagaimana menggunakan bahasa yang baik untuk media luar ruang yang akan mereka buat selanjutnya. Dalam hal ini, fungsi dan peran tim $\mathrm{PkM}$ adalah menjadi fasilitator, stimulator, dan konsultan kebahasaan.

Berdasarkan uraian di atas, luaran kegiatan ini dapat dikelompokkan menjadi dua, yakni luaran langsung dan tidak langsung. Luaran langsung dari PKM ini adalah seri foto digital sebagai database berupa foto-foto media luar ruang yang dipasang di tempat-tempat strategis sebagai sarana informasi tentang pandemi Covid-19 beserta cara pencegahan dan hidup bersih sesuai dengan protokol kesehatan. Sementara itu, luaran tidak langsungnya dapat disebutkan sebagai berikut.

1. Warga masyarakat dapat memiliki pemahaman dan kemampuan yang terus berkembang dalam menggunakan bahasa secara efektif sesuai dengan keperluannya.

2. Warga masyarakat dapat membuat media luar ruang secara persuasif sesuai dengan keperluannya sehingga dapat diterima masyarakat luas secara optimal dan berkualitas.

\section{Pelaksanaan Program}

\section{Aktivitas Pelatihan}

Pelatihan secara daring melibatkan 25 anggota masyarakat sasaran yang dilaksanakan pada Senin, 7 September 2020, pukul 19.30-20.40 WIB, dengan memakai Google Meet (http://meet.google.com/jsy-bomg-ijr). Pelatihan itu menghadirkan narasumber Zulisih Maryani, S.S., M.A., Lektor pada Fakultas Seni Media Rekam, ISI Yogyakarta. Hasil rekaman pelatihan dapat dilihat di https://drive.google.com/drive/ folders/1qpQBFCTIBzwuLP6GgaSRqo PITkAoI9p y?usp=sharing.

\section{Baban Pelatiban}

Bahan atau materi daring disesuaikan dengan dua target kemampuan, yakni kemampuan penggunan bahasa Indonesia secara tepat, efektif, dan persuasif serta kemampuan mendesain media luar ruang yang informatif, menarik, dan persuasif pula. Bahan yang dipakai dalam pelatihan pengembangan kemampuan bahasa diperoleh dari Cermat 

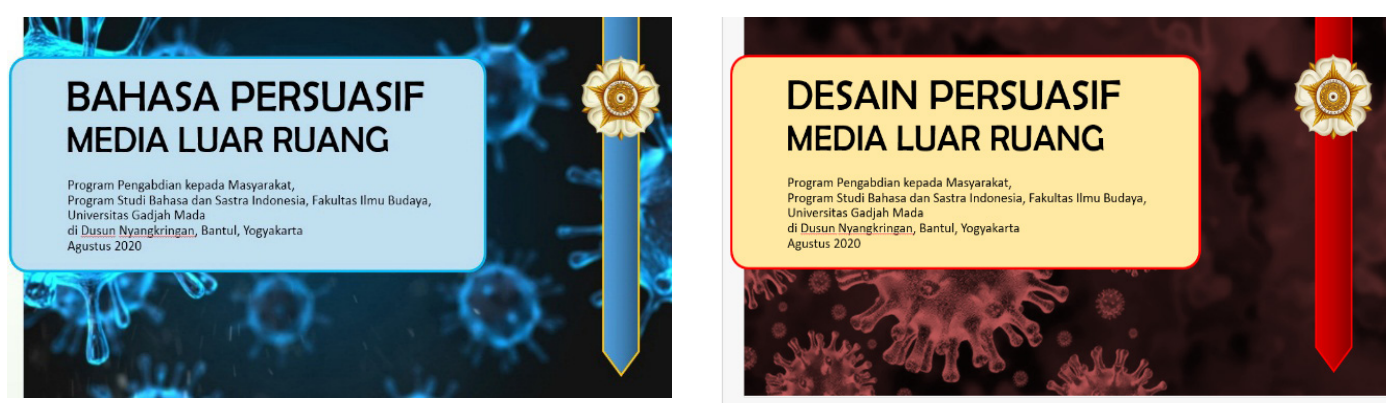

Gambar 1. Cuplikan Layar Materi Pelatihan Bahasa dan Desain Persuasif Media Luar Ruang

Menulis dalam Bahasa Indonesia (Wibowo, 2020) dan "Penggunaan Bahasa Indonesia dalam Surat Dinas" (Wibowo, 2016). Sementara itu, bahan terkait dengan desain media luar ruang disarikan dari berbagai sumber di internet. Kedua materi itu diwujudkan dalam dua PowerPoint berikut ini.

Dari kedua tayangan tersebut berkembanglah interaksi antara pemateri dan peserta yang dapat diwakili dengan pertanyaan-pertanyaan berikut.

1. Apakah persuasi bisa dipakai dalam keperluan sehari-hari? Apa contohnya?

2. Apakah kekerasan bisa muncul dalam bentuk komunikasi verbal/kata-kata? Contohnya bagaimana?

3. Mengapa persuasi perlu menghindari muatan kekerasan verbal?

4. Apakah bahasa persuasif boleh melibatkan bahasa Jawa?

5. Apa pengaruhnya bahasa persuasif pada perilaku masyarakat setempat dan orang luar yang membacanya?

6. Bagaimana komposisi warna, huruf, background, atau infografis pada media luar ruang agar enak dilihat dan pesannya sampai?

\section{Aplikasi Pelatihan}

Seusai pelatihan, selang beberapa hari kemudian, para peserta membuat media luar ruang berupa baliho 3x4 meter $^{3}$ dan dipasang di jalan-jalan utama serta di Gedung Praktik (Sanggar Kerja) STM 1 Muhammadiyah, Bantul, di depan Masjid An-Nur dan di samping kantor Karang Taruna, yakni di depan Pos Ronda. Beberapa baliho ditempatkan di sejumlah lokasi strategis lainnya. Lihat gambar 2.

\section{Tahap Evaluasi}

Pemasangan baliho bermediakan bahasa luar ruang persuasif dimaksudkan sebagai pengingat kepada warga kampung serta warga luar kampung yang melintas untuk selalu mematuhi protokol kesehatan pada masa pandemi ini. Baliho yang telah terpasang kemudian dievaluasi dengan mengadakan wawancara singkat kepada pembuat dan orang yang melihat serta memperhatikan baliho itu. Kepada pembuat baliho dievaluasi alasan mereka memilih kosakata, emphasis, dan struktur tertentu untuk mengekpresikan gagasannya ke dalam konten baliho. Selain itu, dikonfirmasi pula desain yang telah mereka buat terkait dengan ukuran, lokasi, separasi warna, penempatan teks dan gambar, juga proporsinya. Kepada khalayak yang lewat dan memperhatikan baliho juga dilakukan

3 https://blog.printerqoe.com/cara-menarik-perhatian-orang-agar-membaca-spanduk-anda. 


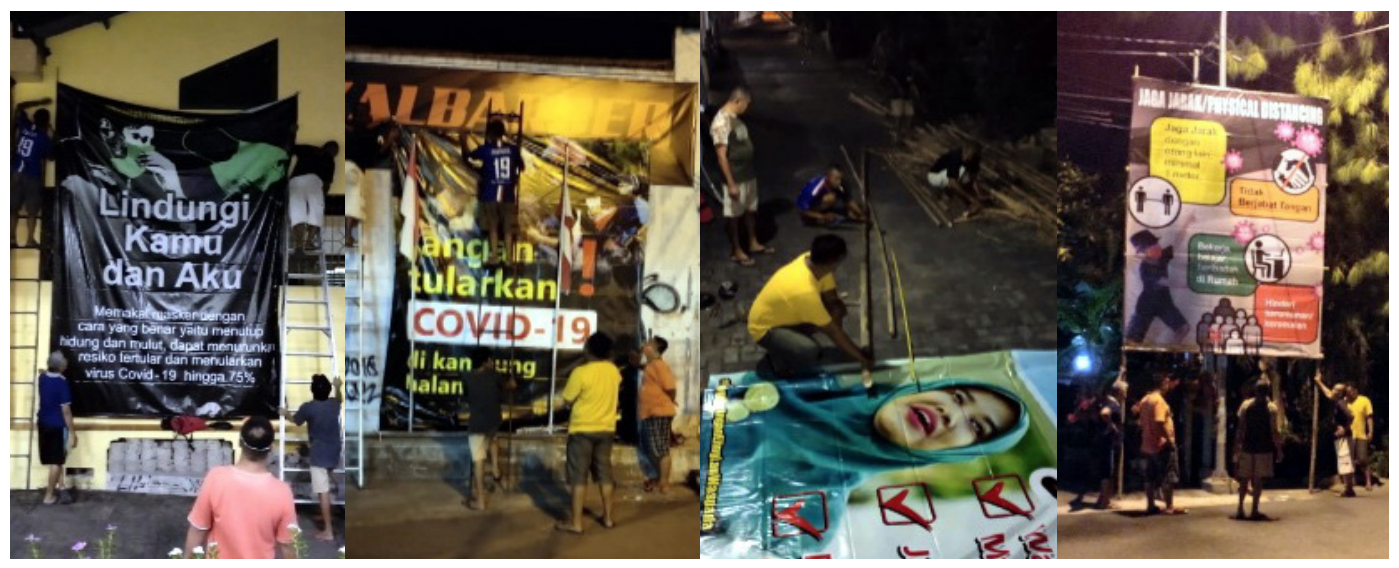

Gambar 2. Pemasangan Baliho Hasil Karya para Peserta Pelatihan
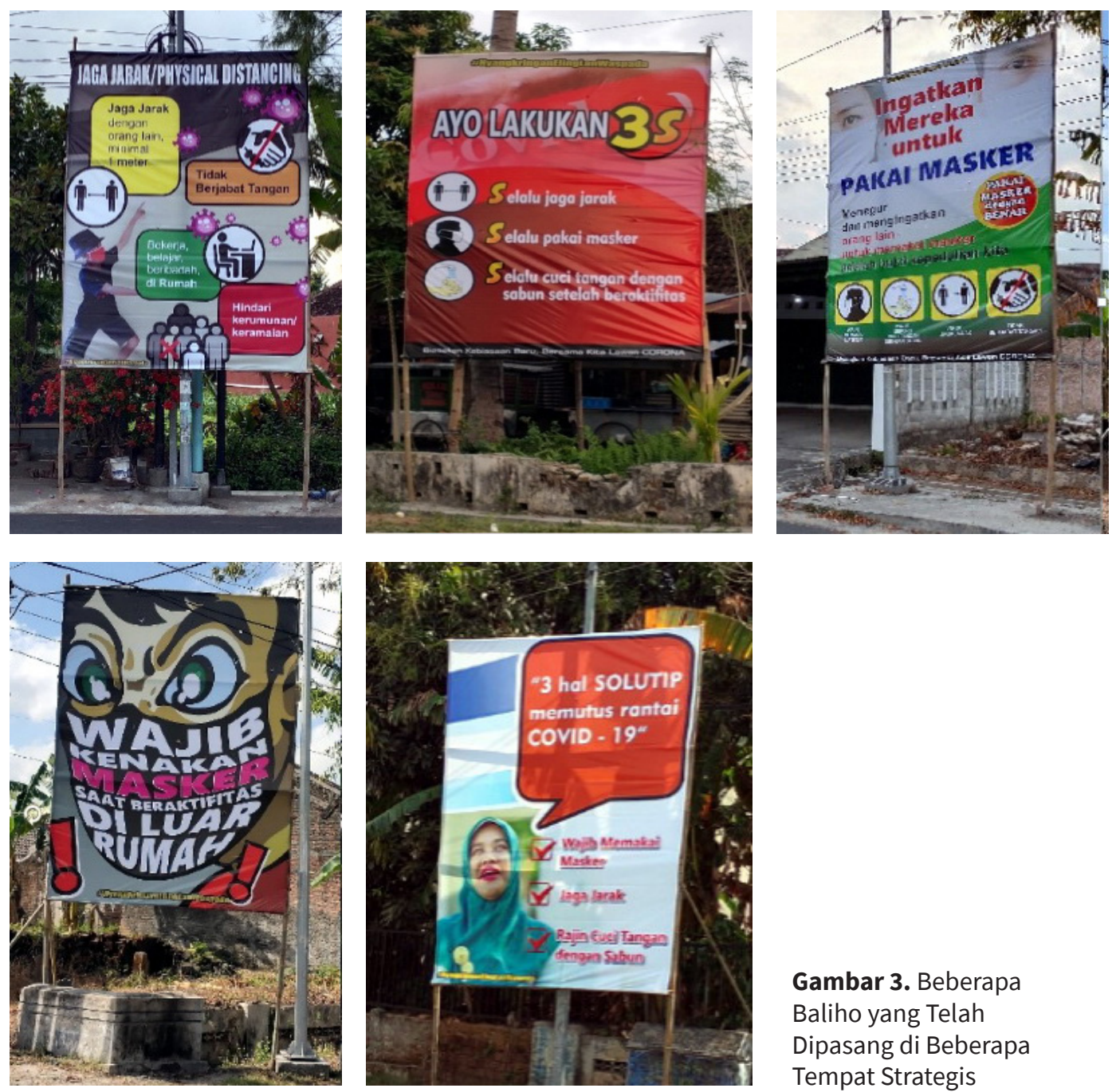

Gambar 3. Beberapa

Baliho yang Telah

Dipasang di Beberapa

Tempat Strategis 
wawancara singkat terkait dengan apakah mereka mengerti pesan yang disampaikan secara mudah, cepat, dan efektif. Hal lain yang telah dikonfirmasi ialah soal desain yang berkaitan dengan struktur baliho mengikuti pandangan Islamiyati ${ }^{4}$ yang di dalamnya terkandung judul promo yang menarik, penjelasan singkat produk, alasan, garansi, bonus, call to action, dan N.B. Selain itu, ditanyakan pula kesan mereka tentang fontasi, separasi warna, visualisasi, dan proporsi. Hasil yang diperoleh cukup menggembirakan karena dominan orang yang melintas dan memperhatikan baliho itu menyatakan bahwa desain baliho cukup mencolok, menarik, dan informatif. Lihat gambar 3.

\section{Refleksi Capaian Program}

\section{Dampak Pemasangan Balibo}

Beberapa hari setelah pemasangan baliho, tampak adanya perubahan perilaku pada sebagian masyarakat di Dusun Nyangkringan. Takmir masjid sangat ketat menerapkan protokol kesehatan. Jemaah yang beribadah diukur suhu tubuhnya, sementara jemaah yang tidak memakai masker diminta pulang untuk memakai masker. Toko-toko dan warung-warung di seputaran kampung juga tidak melayani pembeli yang tidak memakai masker. Poster-poster kecil dan flyer ditempel dan ditempatkan di depan toko untuk mengingatkan pembeli yang akan melakukan kegiatan di dalam warung dan/atau toko.

Dengan penyelenggaraan pengabdian kepada masyarakat yang di dalamnya sejumlah peserta dimotivasi untuk dapat meningkatkan kemampuan penggunaan bahasa yang tepat dan mendesain media luar ruang yang persuasif, tampak adanya perubahan perilaku anggota masyarakat yang cukup signifikan. Mulanya banyak anggota masyarakat yang abai terhadap protokol kesehatan dan bahayanya terjangkit Covid-19. Kini, masyarakat menjadi sadar akan pentingnya kesehatan dengan menjaga diri dan keluarganya dengan mengikuti protokol kesehatan yang telah ditetapkan oleh pemerintah.

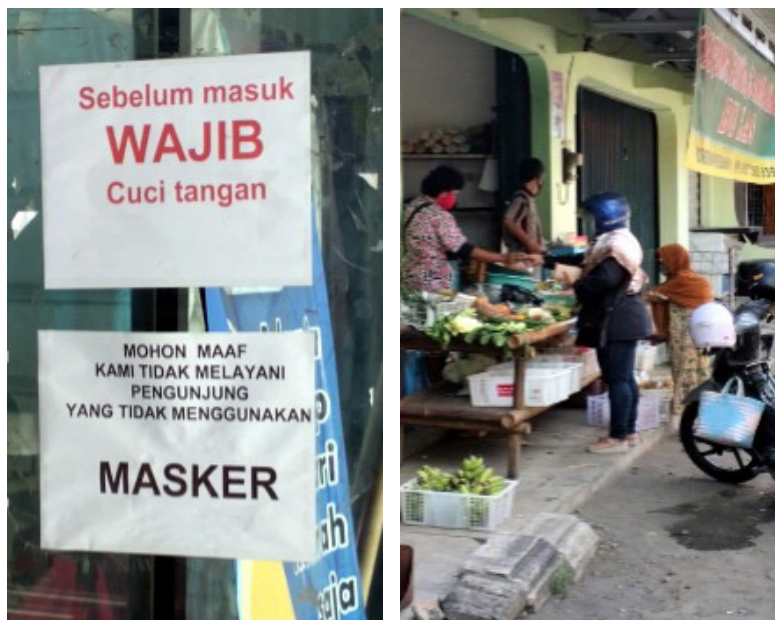

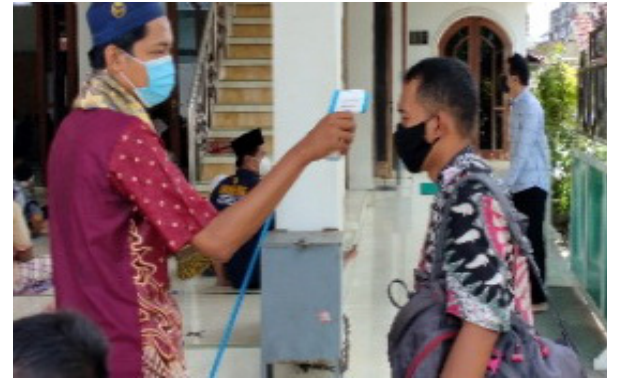

Gambar 4. Masyarakat Dusun Nyangkringan yang Mulai Sadar untuk Menerapkan Protokol Kesehatan

4 https://mebiso.com/ cara-membuat-kalimat-promosi-yang-menarik-biar-omzet-andameningkat/. 


\section{Penutup}

Dari uraian di atas dapat diketahui bahwa apa yang telah direncanakan dalam pengabdian kepada masyarakat mendapatkan hasil yang cukup memuaskan. Dengan pendekatan bahasa yang setiap hari dipakai sebagai sarana komunikasi antarwarga masyarakat Dusun Nyangkringan dapat dikembangkan kemampuan pemakaian bahasa yang efektif dan kemampuan membuat desain media luar ruang yang persuasif. Pada masa yang akan datang, kemampuan pemakaian bahasa yang cukup baik ini dapat dikembangkan lagi untuk berbagai media lain sesuai dengan peruntukannya, khususnya pemakaian bahasa Indonesia secara persuasif dalam media luar ruang, seperti banner, spanduk, edaran, dan billboard. Hasil pengamatan menunjukkan bahwa penggunaan media luar ruang yang telah didesain dengan pemakaian bahasa yang tepat dan desain yang menarik memiliki kontribusi terhadap perubahan perilaku warga Dusun Nyangkringan dan warga luar kampung untuk mematuhi protokol kesehatan selama masa pandemi Covid 19 ini.

\section{Daftar Referensi}

Hasanudin, C. (2017). "Analisis Kesalahan Berbahasa pada Penulisan Media Luar Ruang di Kabupaten Bojonegoro" dalam Jurnal Pendidikan Bahasa dan Sastra. Juni. Bojonegoro: IKIP PGRI

Nugroho, A.T. (2010). "Proses Produksi dalam Pembuatan Iklan Luar Ruang (Outdoor) di Media Artha Advertising” Tugas Akhir. Surakarta: Program Diploma III Periklanan Fakultas Ilmu Sosial dan Ilmu Politik Universitas Sebelas Maret.

Nurkumala, E.I., Ahmad R.M., dan Agus S. (2017). "Penggunaan Bahasa pada Penulisan Luar Ruang di Kota Ketapang" dalam Neliti: Jurnal Pendidikan dan Pembelajaran Untan, Juli. Tanjungpura: Universitas Tanjungpura.

Wibowo, R.M. (2016). "Penggunaan Bahasa Indonesia dalam Surat Dinas". Artikel. Yogyakarta: Belum diterbitkan.

. (2020). "Pemakaian Bahasa dalam Spanduk Peringatan Covid-19 di

Daerah Istimewa Yogyakarta.” Artikel. Yogyakarta: Belum diterbitkan. (2020). Cermat Menulis dalam Bahasa Indonesia. Cet. 4 (Revisi ISBN).

Yogyakarta: A.Com Printing.

\section{Daftar Laman}

https://blog.printerqoe.com/cara-menarik-perhatian-orang-agar-membaca-spandukanda diakses pada 2 Agustus 2020 pukul 14.59 WIB.

https://kusnantokarasan.com/2015/11/01/nama-nama-dusun-desa-dan-kecamatanse-kabupaten-bantul/ diakses pada 6 September 2020 pukul 13.35 WIB.

https://mebiso.com/cara-membuat-kalimat-promosi-yang-menarik-biar-omzet-andameningkat/ diakses pada 19 Agustus 2020 pukul 21.48 WIB.

https://mediamove.id/jenis-jenis-media-luar-ruangan-yang-paling-poluler/ diakses pada 2 Agustus 2020 pukul 13.47 WIB.

https://solusiprinting.com/berbagai-kelebihan-dan-kekurangan-media-luar-ruang/ diakses pada 2 Agustus 2020 pukul 14.38 WIB. 